\title{
De paradox binnen het Jeugd- en Rechtsbeschermingsbeleid
}

W

etgever, bestuurders, gemeenten, organisaties en professionals: ze beogen met hun beleid en uitvoering allemaal de bescherming van het kind. Maar in de praktijk leidt het juist vaak tot verergering van de problemen. Door beter aan te sluiten op de dagelijkse praktijk van het kind en de oorzaak van zijn problemen, kan de druk op het gemeentebudget, het zorgstelsel en het juridisch bestel omlaag. Dat is goed voor het welzijn van het kind, en uiteindelijk ook voor de belastingbetaler.

In de Nederlandse samenleving benaderen we altijd het kind én zijn ouders. Dat uitgangspunt is uitsluitend gebaseerd op de stelling dat het kind altijd loyaal is aan beide ouders. Met name bij scheiding is de gehele keten van Jeugd- en Rechtsbescherming gericht op het - met toenemende drang en dwangmaatregelen - verplichten van ouders om gezamenlijk tot overeenstemming te komen, zodat het kind geen loyaliteitsproblemen ontwikkelt. Ontwikkelt het kind wel problemen, dan wijst men het loyaliteitsconflict aan als oorzaak en gaat de bal terug naar de ouders, die op deze manier honderd procent afhankelijk van elkaar blijven. De paradox: de huidige visie is gebaseerd op controle over beide ouders.

\section{In de knel}

Maar wat als de oorzaak van de problemen van het kind ligt in het fysiek of psychisch misbruik door één van beide ouders? Dan leidt dit beleid voor het kind en de andere ouder die het kind wenst te beschermen, tot vergaande machteloosheid. Voor kinderen is het ernstig traumatiserend niets te mogen zeggen over deze ervaringen. De beschermende ouder mag niets melden over de ervaringen van het kind. Het kind én de ouder zitten in de knel. De misbruikende ouder die niet bereid of in staat is (ggz) wordt op deze manier slechts gevoed om nimmer tot overeenstemming te komen en (o.a. de loyaliteit van) het kind te blijven misbruiken en in te zetten in de communicatie richting de andere ouder en zo beiden afhankelijk te houden. Kinderen worden gediagnosticeerd met individuele problematiek zoals angst- en paniekstoornissen, suïcidaliteit en PTSS, terwijl er in feite sprake is van structureel misbruik en machteloosheid. Het kind heeft recht op bescherming van de autonomie en het recht om zowel in constructieve als destructieve relaties altijd loyaal te zijn aan zichzelf.

Wij stellen een bredere visie voor, waarin beide ouders zijn gehouden aan neutraal ouderschap. Op basis van de deskundigheid van de professional om misbruik vroeg te kunnen signaleren, wordt vervolgbeleid bepaald en doorgevoerd in de gehele keten van Jeugd- en Rechtsbescherming. Met het vertrouwen in de eigen deskundigheid kan het kind in zijn ervaringen en zijn positie worden erkend, evenals de ouder. De misbruikende ouder wordt binnen een neutraal kader deskundig begrensd. Dit aanvullende beleid is niet gebaseerd op controle over ouders, maar op vertrouwen in een ouder die in staat is te handelen binnen het kader van neutraal ouderschap en het versterken van de regie van het kind.

Joke de Jong, Neutraal Ouderschap,

Miriam Goes, ervaringsdeskundige

www.neutraalouderschap.nl

\section{In de Nederlandse}

samenleving bena-

deren we altijd het

kind én zijn ouders.

\section{Het kind heeft recht}

om altijd loyaal te

zijn aan zichzelf. 